\title{
Validation of the alkane technique to estimate diet selection of goats grazing heather-gorse vegetation communities
}

\author{
Luis MM Ferreira, ${ }^{1 *}$ Mamen Oliván, ${ }^{2}$ Urce Garcia, ${ }^{2}$ Miguel AM Rodrigues ${ }^{1}$ \\ and Koldo Osoro ${ }^{2}$ \\ ${ }^{1}$ CECAV, Departamento de Zootecnia, Universidade de Trás-os-Montes e Alto Douro, PO Box 1013, 5000-911 Vila Real, Portugal \\ ${ }^{2}$ SERIDA, Servicio Regional de Investigación y Desarrollo Agroalimentario, PO Box 13, 33300 Villaviciosa, Asturias, Spain
}

\begin{abstract}
The effect of $\boldsymbol{n}$-alkane faecal recovery on the accuracy of diet composition estimates, when increasing the number of diet components, was studied. Seven dietary treatments, composed of different proportions of herbaceous (Lolium perenne and Trifolium repens) and woody species (Erica umbellata, Erica cinerea, Calluna vulgaris, Erica arborea and Ulex gallii) were offered to 28 goats housed in metabolism crates. Diet composition was estimated from alkane concentrations in diet and faeces, with and without correction for incomplete faecal recoveries, using least-squares procedures and was compared with the known diet proportions. There were no significant differences between measured proportions of dietary components and those estimated with alkanes when applying the faecal recovery corrections. In contrast, the proportions calculated without faecal recovery correction differed significantly $(p<0.05)$ from the actual proportions, overestimating feeds with higher content of long-chain $n$-alkanes. The diet composition affected significantly the faecal recovery of alkanes if there were significant differences on in vivo digestibility. The $n$-alkane faecal recoveries decreased as the diet digestibility increased. The results obtained show that the application of the alkane methodology for grazing animals should be preceded by calculation of the actual alkane faecal recoveries for each type of vegetation community and experimental conditions.

(C) 2005 Society of Chemical Industry
\end{abstract}

Keywords: shrubs; goats; diet composition; $n$-alkanes

\section{INTRODUCTION}

Large land extensions around the world are covered by shrubland, dominated by different woody species varying with soil and climatic conditions. Most of these areas are less favoured and undeveloped areas and, therefore, it is necessary to find ways for the development and sustainability of these large areas and use by grazing animals is a possibility.

It is recognized that there are clear differences between animal species ${ }^{1}$ even between breeds ${ }^{2}$ in their grazing behaviour and performance and in their impact on vegetation dynamics and biodiversity. ${ }^{3}$

The understanding of the grazing behaviour, mainly the diet selection, of the different animal species and breeds under different conditions is essential to develop sustainable grazing and management systems.

The capacity of goats as browsers ${ }^{4,5}$ is well known. The possibility of using $n$-alkanes and other natural markers for estimating diet composition has been assessed. ${ }^{6-8}$ When using $n$-alkanes for estimating diet composition, an important factor to consider is the faecal recoveries of these markers. Alkane faecal recoveries are not complete, varying with alkane chain length..$^{8-10}$ Therefore, the accuracy of diet estimates may change according to the $n$-alkanes present in the feed components (as well as with their concentrations) that the animals are eating. The majority of the studies with alkanes have been conducted with sheep and with vegetation where herbaceous species were dominant. ${ }^{1-13}$ The objective of the present work was to investigate the accuracy of using $n$-alkanes to estimate diet composition of goats when varying the proportions of browse and herb feeds in order to apply this technique to goats grazing mosaics of heather-gorse communities interspersed by patches of grass and clover. For this purpose, seven different diets, with varying proportions of grass-clover and shrubs (Erica sp and Ulex gallii) were offered to goats in a metabolic crate study.

\section{MATERIALS AND METHODS \\ Experimental site and design}

This study was conducted at Carbayal Research Station, situated $900-1000 \mathrm{~m}$ above sea level, at San

* Correspondence to: Luis MM Ferreira, CECAV, Departamento de Zootecnia, Universidade de Trás-os-Montes e Alto Douro, PO Box 1013, 5000-911 Vila Real, Portugal

E-mail: Imf@utad.pt

Contract/grant sponsor: CICYT (Comisión Interministerial de Ciencia y Tecnología); contract/grant number: AGL2003-05342/GAN

(Received 26 July 2004; revised version received 22 October 2004; accepted 14 December 2004)

Published online 31 March 2005 
Table 1. Proportions of different components of diets offered in each experimental period to each group

\begin{tabular}{|c|c|c|c|c|c|c|c|}
\hline Groups & $L$ perenne ${ }^{\mathrm{a}}$ & $L$ perenne ${ }^{\mathrm{b}}$ & Meadow hay & Trepens & Heaths & E arborea & $\cup$ gallii \\
\hline \multicolumn{8}{|c|}{ Period 1 (May) } \\
\hline G1 & 0.71 & - & - & - & - & - & 0.29 \\
\hline G2 & 0.71 & - & - & - & 0.29 & - & - \\
\hline \multicolumn{8}{|c|}{ Period 2 (July) } \\
\hline G3 & 0.28 & 0.11 & - & - & 0.30 & - & 0.30 \\
\hline G4 & 0.39 & - & - & 0.30 & 0.31 & - & - \\
\hline \multicolumn{8}{|c|}{ Period 3 (October) } \\
\hline G5 & - & - & 0.40 & - & 0.30 & - & 0.30 \\
\hline G6 & - & - & 0.40 & - & 0.30 & 0.30 & - \\
\hline G7 & - & - & 0.40 & - & - & 0.30 & 0.30 \\
\hline
\end{tabular}

${ }^{a}$ Leaf/stem.

b Spike.

Isidro's Mountain, Asturias, Spain (longitude $6^{\circ} 53^{\prime}$, latitude $\left.43^{\circ} 21^{\prime}\right)$. Vegetation is dominated by a mosaic of gorse-heathland interspersed with small areas of improved pastures (Lolium perenne and Trifolium repens).

Seven experimental diets (Table 1) were offered to seven different groups of four non-lactating goats in order to validate the $n$-alkane technique with different diets. The experimental diets were distributed in three experimental periods of 11 days each carried out in May (two trials), July (two trials) and October (three trials) of 2003 (Table 1) in order to dispose of current season's green shoots of the main plant species. Thus, the species composition of the diets reflected the evolution of the vegetation availability during the summer grazing season (May to October) and the grazing behaviour of goats on these vegetation conditions observed in previous studies. ${ }^{14}$

Each experimental period comprised a 7-day adjustment period for adaptation of the animals to the diets and experimental conditions, followed by a 4-day period of collection of samples of faeces and diet components. Freshly cut vegetation samples ( $L$ perenne, $T$ repens and green shoots of the woody species) were harvested from random sites within the experimental field and were offered twice a day (9:00 and $18: 00 \mathrm{~h}$ ) in equal proportions to the animals, without refusals. One sample of the total faecal output was collected every 2 days and a daily sample of each diet component was collected before the morning meal. During the experiments, animals were housed in individual metabolic crates to allow total collection of faeces and urine. Prior to the trial, the animals were grazing on a shrubland, composed by different woody species (Ulex gallii, Erica umbellata, Erica cinerea, Erica arborea and Calluna vulgaris) used in the experimental diets.

\section{Animals and diets}

In the first experimental period (May), eight crossbreed goats were distributed into two groups of four animals: G1 (24 $\pm 1.4 \mathrm{~kg}$ live weight) and G2 $(22 \pm 1.1 \mathrm{~kg}$ live weight). These goats received a daily total amount of $1.0 \mathrm{~kg} \mathrm{DM} 100 \mathrm{~kg}^{-1}$ live weight of a diet composed by different combinations of herbaceous (Lolium perenne) and woody species (U gallii and heaths; Table 1).

In the second experimental period (July), eight crossbreed goats, divided into two groups of four animals, G3 (26 $\pm 1.5 \mathrm{~kg}$ live weight) and G4 (29 \pm $1.0 \mathrm{~kg}$ live weight) received $0.8 \mathrm{~kg} \mathrm{DM} 100 \mathrm{~kg}^{-1}$ live weight of a diet composed of herbaceous ( $L$ perenne leaf/stem, $L$ perenne spike and Trifolium repens) and woody ( $U$ gallii and heaths) species (Table 1$)$.

In the third experimental period (October), twelve crossbreed goats were used, divided into three groups of four animals: G5 (28 $\pm 1.8 \mathrm{~kg}$ live weight), G6 $(25 \pm 0.7 \mathrm{~kg}$ live weight) and G7 $(22 \pm 0.7 \mathrm{~kg}$ live weight). These goats received a daily total amount of $0.8 \mathrm{~kg} \mathrm{DM} 100 \mathrm{~kg}^{-1}$ live weight of a diet composed of meadow hay, heaths, $E$ arborea and $U$ gallii. The main plant species present in the meadow hay were $L$ perenne and $T$ repens.

The botanical composition of the vegetation component called 'heaths' represents the field proportion of different plant species of shrubland, namely $E$ umbellata, $E$ cinerea and $C$ vulgaris, at each experimental period. Thus, the proportions of these species in the mixture called 'heaths' varied between experimental periods. In October, the heath $E$ arborea (tall heath) was included in the diet since previous studies showed that in this period $E$ arborea is selected by goats. ${ }^{14}$ This plant species was included in the diet calculations as a different component, as preliminary results showed that this species has a different $n$-alkane pattern relative to other heaths. However, other heath species ( $E$ umbellata, $E$ cinerea and $C$ vulgaris) were maintained as a sole botanical group in order to test if the $n$-alkane technique could discriminate the main shrubland group (heaths) from a unique sample of heterogeneous composition collected in the field.

\section{Chemical analysis}

Samples of the diet components and faeces were immediately dried on the day of collection, using a forced-air oven at $60^{\circ} \mathrm{C}$ for $72 \mathrm{~h}$, for dry matter determination. The samples for alkane analyses were immediately frozen at $-20^{\circ} \mathrm{C}$ and then freeze-dried and milled through a $1-\mathrm{mm}$ screen. 


\section{Alkane analysis}

Alkane content of individual samples of diet components (four for each diet component) and faeces (two for each animal) were analyzed in duplicate by direct saponification according to the methods of Mayes et $a l^{15}$ modified by Oliván and Osoro. ${ }^{16}$

The first stage involved a saponification of $0.5 \mathrm{~g}$ of faeces or $1.5 \mathrm{~g}$ of vegetation components for $14 \mathrm{~h}$ in $7 \mathrm{ml}$ of $1 \mathrm{M} \mathrm{KOH}$ ethanolic at $90^{\circ} \mathrm{C}$ in a dryblock heater (Techne DB-3, Techne Ltd, Duxford, Cambridge, UK). Afterwards, a hot extraction was performed with $n$-heptane at $65^{\circ} \mathrm{C} .{ }^{16}$ After the extraction, the sample was passed through a silicagel column (bed volume $5 \mathrm{ml}$ ), to separate the alkanes from pigments, sterols and alcohols. Samples eluted from the columns were evaporated to dryness, and then redissolved in $500 \mu 1$ of heptane for chromatographic analysis.

Quantification of the alkanes was carried out by gas chromatography, using a Varian 3400 GC, equipped with flame ionisation detector (FID), an 8200 autosampler and a temperature-programmable injector.

Alkane extracts were injected $(0.5 \mu \mathrm{l})$ by on-column injection on a $15-\mathrm{m}$ column DB-1 megabore of $0.530 \mathrm{~mm}$ internal diameter and $1.5 \mu \mathrm{m}$ film thickness. Helium was used as carrier gas at a constant flow of $15 \mathrm{ml} \mathrm{min}{ }^{-1}$. Gradients of temperature were used for the injector $\left(80^{\circ} \mathrm{C}\right.$ for $0.2 \mathrm{~min} ; 200^{\circ} \mathrm{C} \mathrm{min}{ }^{-1}$ to $\left.380^{\circ} \mathrm{C}\right)$ and the column $\left(200^{\circ} \mathrm{C}\right.$ for $1 \mathrm{~min} ; 6^{\circ} \mathrm{C} \mathrm{min}{ }^{-1}$ to $300^{\circ} \mathrm{C} ; 6 \mathrm{~min}$ at $300^{\circ} \mathrm{C}$ ). The detector oven was maintained at $350^{\circ} \mathrm{C}$.

Gas chromatographic method was calibrated with a standard solution containing a mixture of synthetic alkanes $\left(\mathrm{C}_{23}\right.$ to $\left.\mathrm{C}_{36}\right)$ with concentrations similar to those found in extracts. The response factors for individual alkanes were calculated from peak areas and the known concentrations. The detector response to varied concentrations of each solute was linear throughout the range of concentrations found in the injected samples. Alkane concentrations were quantified relative to known amounts of the internal standards $\mathrm{C}_{22}$ (n-docosane) and $\mathrm{C}_{34}$ (ntetratriacontane), added at the beginning of the extraction process. The use of two internal standards enabled the evaluation of the effectiveness of the extraction process and the correction of the peak areas for any discrimination detected during the solventextraction step. ${ }^{16}$

\section{Calculations}

Alkane faecal recoveries (AFR) were calculated from the total amount of each $n$-alkane consumed that was excreted in faeces (eqn (1)):

$$
\begin{aligned}
\operatorname{AFR}_{i}(\%)= & \frac{\mathrm{F} \times \mathrm{F}_{i}}{\mathrm{~A} \times \mathrm{A}_{i}+\mathrm{B} \times \mathrm{B}_{i}+\ldots \ldots+\mathrm{Z} \times \mathrm{Z}_{i}} \\
& \times 100
\end{aligned}
$$

where $\mathrm{AFR}_{i}$ is the faecal recovery of alkane $i, \mathrm{~F}$ is the faecal DM output, and $\mathrm{F}_{i}$ the faecal concentration of alkane $i$. A, B to $\mathrm{Z}$ are the amounts of the diet components $\mathrm{A}, \mathrm{B}$ to $\mathrm{Z}$ consumed over the entire period and $\mathrm{A}_{i}, \mathrm{~B}_{i}$ to $\mathrm{Z}_{i}$ the alkane $i$ concentrations in $A, B$ to $Z$, respectively.

Diet composition was estimated using an optimization procedure which minimizes the sum of squared discrepancies between the actual (A) alkane proportions in faeces (adjusted for the incomplete faecal recoveries) and the estimated (E) proportions (different combinations of diet components), as follows: ${ }^{17,18}$

$$
\begin{aligned}
\sum_{i=1}^{n}[\mathrm{~A}-\mathrm{E}]^{2}= & \sum_{i=1}^{n}\left[\frac{\mathrm{F}_{i}}{\mathrm{~F}_{\mathrm{t}}}-\frac{a \mathrm{~A}_{i}+b \mathrm{~B}_{i}+\ldots \ldots z Z_{i}}{a \mathrm{~A}_{\mathrm{t}}+b \mathrm{~B}_{\mathrm{t}}+\ldots \ldots z Z_{\mathrm{t}}}\right]^{2} \\
& \times \text { minimal }
\end{aligned}
$$

where $a, b$ to $z=(1-a-b-\ldots)$ are the proportions of components $\mathrm{A}, \mathrm{B}$ to $\mathrm{Z}$ in the $\operatorname{diet} ; \mathrm{F}_{i}, \mathrm{~A}_{i}, \mathrm{~B}_{i}$ to $\mathrm{Z}_{i}$ are the concentrations of alkane $i$ in faeces (corrected for incomplete faecal recovery) and components $\mathrm{A}, \mathrm{B}$ to $Z ; F_{t}, A_{t}, B_{t}$ to $Z_{t}$ are total alkane concentrations in faeces and components $\mathrm{A}, \mathrm{B}$ to $\mathrm{Z}$.

In vivo dry matter digestibility (DMD) was calculated from total faecal collection using the equation:

$$
\mathrm{DMD}\left(\mathrm{g} \mathrm{kg}^{-1} \mathrm{DM}\right)=\frac{\mathrm{I}-\mathrm{F}}{\mathrm{I}} \times 1000
$$

where $\mathrm{I}$ is the total intake and $\mathrm{F}$ the total faecal output.

\section{Other analyses}

Ash and nitrogen were determined following the procedures of the Association of Official Analytical Chemists. ${ }^{19}$ Neutral detergent fibre (NDF), acid detergent fibre (ADF) and acid detergent lignin (ADL) were determined by the method of Van Soest et al. ${ }^{20}$ Hemicellulose and cellulose were calculated as the difference between NDF and ADF and between ADF and ADL, respectively.

\section{Statistical analysis}

Statistical analyses were carried out using the JMP program. ${ }^{21}$ Differences between species in the alkane profiles were explored using principal components analysis (PCA). The significance of the effect of diet digestibility on the recovery of each alkane in faeces was analyzed by linear regression.

The effect of diet composition within each experimental period (May, July, October) on $n$-alkane faecal recoveries and in vivo dry matter digestibility (DMD) were examined by one-way analysis of variance (ANOVA). The effect of calculation method for diet composition estimates (measured, estimated with faecal recovery correction, estimated without recovery correction) was examined by analysis of variance. When the $F$-test for calculation method was significant $(p<0.05)$, multiple comparisons among means were examined by the Tukey test. 


\section{RESULTS AND DISCUSSION}

The chemical composition of the feeds used in the different experiments is presented in Table 2. As expected, cell wall components represented the highest fraction in all diet components. The results obtained for heaths are in agreement with the chemical composition data reported by Hogdson and Eadie. ${ }^{22}$ Erica sp (heaths and $E$ arborea) are characterized by high levels of ADL. Furthermore, in the first experimental period, the crude protein (CP) content of $U$ gallii was high $\left(217 \mathrm{~g} \mathrm{~kg}^{-1} \mathrm{DM}\right)$ and comparable with the CP content of $T$ repens $\left(218 \mathrm{~g} \mathrm{~kg}^{-1} \mathrm{DM}\right)$ used in the second experimental period.

The average content of $n$-alkanes in feeds is presented in Table 3. The concentrations of $\mathrm{C}_{22}$ and $\mathrm{C}_{34}$ are not shown as they were used as internal standards in GC analyses. The $n$-alkane concentrations of the vegetation components were similar to those found in previous reports. ${ }^{23-25}$ The odd-chain alkanes comprised the highest fraction in all components, representing between $85.7 \%$ ( $U$ gallii used in the third experimental period) and 94.5\% (meadow hay used in the third experimental period) of the total alkane content. The individual alkanes present in highest concentrations were $\mathrm{C}_{29}$, $\mathrm{C}_{31}$ and $\mathrm{C}_{33}$ in the $L$ perenne leaf/stem (first and second experiments), meadow hay and $E$ arborea (third experiment), and in heaths (all experiments). For $T$ repens, $L$ perenne spike and $U$ gallii used in the first and second experimental periods, the highest concentrations were observed in $\mathrm{C}_{27}, \mathrm{C}_{29}$ and $\mathrm{C}_{31} . U$ gallii supplied to the animals in the third experimental period presented the highest concentrations in $\mathrm{C}_{28}$, $\mathrm{C}_{29}$ and $\mathrm{C}_{31}$. Although the evaluation of the effect of stage of maturity on the $n$-alkane concentrations was not one of the objectives of this study, a decrease in the alkane concentrations of $U$ gallii between the first and the second experimental period, reaching constancy between the second and the third experimental period, was observed as the grazing season progressed from May to October. A similar trend was found by Dove et al ${ }^{26}$ in $\mathrm{C}_{29}$ and $\mathrm{C}_{31}$ concentrations of alfalfa stems (Medicago sativa cv Siriver). However, Smith et $a l^{27}$ did not observe a significant change of alkane concentrations either in leaves or stems components in common species of 40 southern African grasses between dry or wet seasons. These authors suggested that differences in alkane concentrations in whole

Table 2. Chemical composition ( $\left.\mathrm{g} \mathrm{kg}^{-1} \mathrm{DM}\right)$ of diet components used in the different experimental periods

\begin{tabular}{|c|c|c|c|c|c|c|c|c|c|c|c|c|}
\hline \multirow[b]{2}{*}{ Component } & \multicolumn{3}{|c|}{ 1st experimental period (May) } & \multicolumn{5}{|c|}{ 2nd experimental period (July) } & \multicolumn{4}{|c|}{ 3rd experimental period (October) } \\
\hline & $\begin{array}{c}L \\
\text { perenne }^{b}\end{array}$ & Heaths & $\begin{array}{c}U \\
\text { gallii }\end{array}$ & $\begin{array}{c}L \\
\text { perenne }^{b}\end{array}$ & $\begin{array}{c}L \\
\text { perennec }^{c}\end{array}$ & $\begin{array}{c}T \\
\text { repens }\end{array}$ & Heaths & $\begin{array}{c}U \\
\text { gallii }\end{array}$ & $\begin{array}{c}\text { Meadow } \\
\text { hay }\end{array}$ & Heaths & $\begin{array}{c}E \\
\text { arborea }\end{array}$ & $\begin{array}{c}U \\
\text { gallii }\end{array}$ \\
\hline Organic matter & 923.7 & 968.0 & 939.3 & 940.3 & 949.9 & 899.4 & 967.1 & 964.5 & 945.6 & 972.1 & 970.6 & 971.8 \\
\hline Crude protein & 125.1 & 81.5 & 217.3 & 77.3 & 123.7 & 218.0 & 77.6 & 119.5 & 121.6 & 73.3 & 79.3 & 110.0 \\
\hline $\mathrm{NDF}^{\mathrm{a}}$ & 456.2 & 551.9 & 559.9 & 619.3 & 621.5 & 397.5 & 565.4 & 725.4 & 742.3 & 633.7 & 604.7 & 706.4 \\
\hline ADF & 253.5 & 481.4 & 428.2 & 378.2 & 329.6 & 291.2 & 442.1 & 567.3 & 347.3 & 510.1 & 503.9 & 554.2 \\
\hline ADL & 43.7 & 372.3 & 147.0 & 48.6 & 44.1 & 57.4 & 299.7 & 226.4 & 42.3 & 335.3 & 350.1 & 229.9 \\
\hline Cellulose & 209.8 & 109.1 & 281.1 & 329.6 & 285.5 & 233.9 & 142.4 & 341.0 & 305.0 & 174.8 & 153.8 & 324.3 \\
\hline Hemicellulose & 212.0 & 89.9 & 146.9 & 246.0 & 302.8 & 114.8 & 154.1 & 169.6 & 414.1 & 148.5 & 126.3 & 156.1 \\
\hline
\end{tabular}

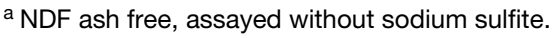

b Leaf/stem.

c Spike.

Table 3. $n$-Alkane content ( $\mathrm{mg} \mathrm{kg}^{-1} \mathrm{DM}$ ) of diet components consumed by goats in the different experimental periods

\begin{tabular}{|c|c|c|c|c|c|c|c|c|c|c|c|c|}
\hline \multirow[b]{2}{*}{ n-Alkane } & \multicolumn{3}{|c|}{ 1st experimental period (May) } & \multicolumn{5}{|c|}{ 2nd experimental period (July) } & \multicolumn{4}{|c|}{ 3rd experimental period (October) } \\
\hline & $\begin{array}{c}L \\
\text { perenne }^{a}\end{array}$ & Heaths & $\begin{array}{c}U \\
\text { gallii }\end{array}$ & $\begin{array}{c}L \\
\text { perenne }^{a}\end{array}$ & $\begin{array}{c}L \\
\text { perenne } \\
\text { b }\end{array}$ & $\begin{array}{c}T \\
\text { repens }\end{array}$ & Heaths & $\begin{array}{c}U \\
\text { gallii }\end{array}$ & Hay & Heaths & $\begin{array}{c}E \\
\text { arborea }\end{array}$ & $\begin{array}{c}U \\
\text { gallii }\end{array}$ \\
\hline $\mathrm{C}_{25}$ & 20.0 & 25.8 & 4.7 & 10.6 & 85.4 & 16.4 & 11.0 & 2.3 & 40.1 & 16.8 & 14.5 & 3.4 \\
\hline $\mathrm{C}_{26}$ & 5.2 & 9.4 & 3.1 & 2.2 & 6.9 & 3.8 & 5.2 & 1.5 & 4.0 & 7.9 & 4.6 & 2.7 \\
\hline $\mathrm{C}_{27}$ & 40.2 & 79.6 & 38.5 & 22.3 & 111.5 & 38.2 & 48.9 & 9.6 & 55.7 & 57.9 & 67.8 & 12.4 \\
\hline $\mathrm{C}_{28}$ & 12.7 & 19.6 & 11.1 & 6.6 & 11.7 & 11.3 & 14.7 & 5.5 & 10.5 & 25.9 & 21.4 & 13.5 \\
\hline $\mathrm{C}_{29}$ & 178.0 & 359.3 & 111.2 & 123.7 & 219.0 & 170.0 & 277.8 & 42.8 & 208.1 & 171.7 & 408.7 & 51.9 \\
\hline $\mathrm{C}_{30}$ & 18.8 & 50.9 & 18.5 & 11.3 & 20.2 & 16.6 & 40.0 & 11.9 & 17.7 & 35.5 & 93.7 & 12.4 \\
\hline $\mathrm{C}_{31}$ & 274.0 & 1142.5 & 269.5 & 234.9 & 337.6 & 206.9 & 900.4 & 157.4 & 376.5 & 788.3 & 1625.8 & 146.4 \\
\hline $\mathrm{C}_{32}$ & 12.0 & 78.1 & 7.3 & 4.8 & 7.8 & 7.3 & 68.6 & 5.3 & 7.9 & 71.2 & 133.9 & 5.2 \\
\hline $\mathrm{C}_{33}$ & 115.4 & 595.7 & 9.6 & 38.9 & 21.9 & 22.2 & 599.4 & 5.3 & 64.4 & 600.0 & 662.2 & 6.6 \\
\hline Total & 698.7 & 2378.2 & 478.8 & 463.1 & 848.8 & 500.6 & 1985.4 & 245.3 & 815.3 & 1865.9 & 2978.8 & 258.7 \\
\hline Total odd-chain & 645.7 & 2214.4 & 434.9 & 435.2 & 796.3 & 458.2 & 1852.8 & 218.5 & 770.5 & 1720.7 & 2721.6 & 221.8 \\
\hline
\end{tabular}

a Leaf/stem.

b Spike. 
plant samples could result from differences in the proportions of plant parts. These results could explain the differences observed between the $L$ perenne used in the first and in the second experiments. According to the alkane concentrations obtained by Dove et $a l^{26}$ for vegetative tissues of perennial ryegrass, the leaf fraction presented higher alkane concentrations than the stem fraction. In the present study the participation of stem in the whole sample increased between the first and the second experimental period, possibly leading to a decrease in the alkane concentrations of the L perenne leaf/stem.

For the heaths group, the same decline in the alkane concentrations along the grazing season (May to October) could be observed. However, since the botanical composition of this group was so diverse $(E$ umbellata, E cinerea and $C$ vulgaris) and the proportions of each species could vary within the group, we cannot know for sure whether the decrease in the alkane concentrations was due to the maturity stage or different botanical composition of heaths between experimental periods.

The PCA indicated, for each experimental period, how different were the $n$-alkane patterns among species. The first two principal components explained 98.3, 94.8 and $81.5 \%$ of the variation in the experimental period 1 (Fig 1), period 2 (Fig 2) and period 3 (Fig 3), respectively. The results obtained from the first experimental period clearly show that all the diet components were different from each other, since they were allocated in three different quadrants. It should be noticed that one replicate of ryegrass

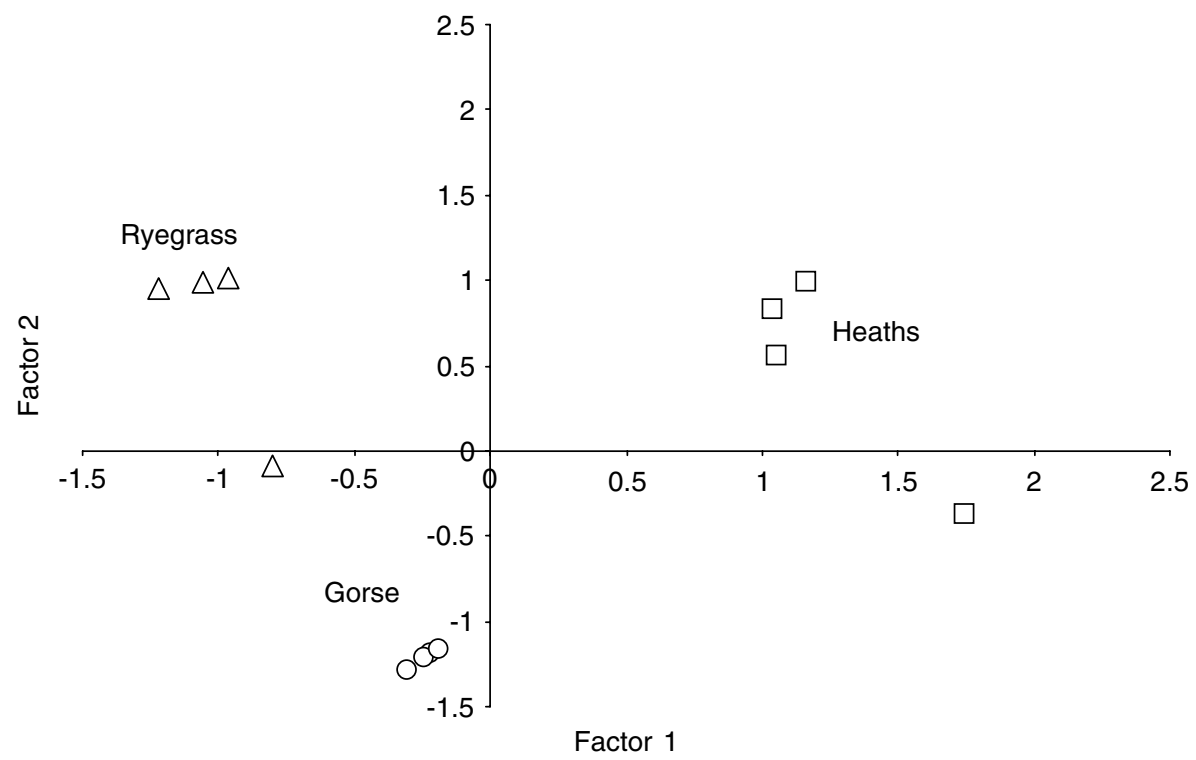

Figure 1. Two-dimensional plot from principal component analysis based on the alkane content of feeds given to groups of non-lactating goats in the first experimental period.

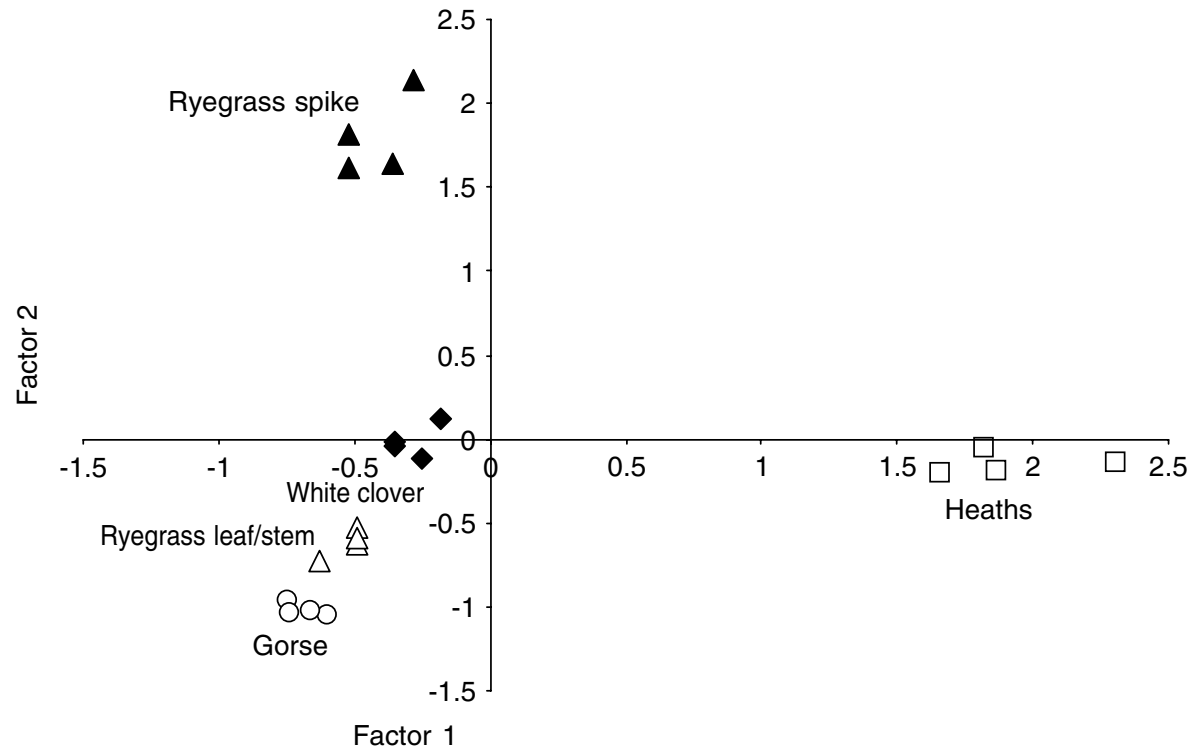

Figure 2. Two-dimensional plot from principal component analysis based on the alkane content of feeds given to groups of non-lactating goats in the second experimental period. 


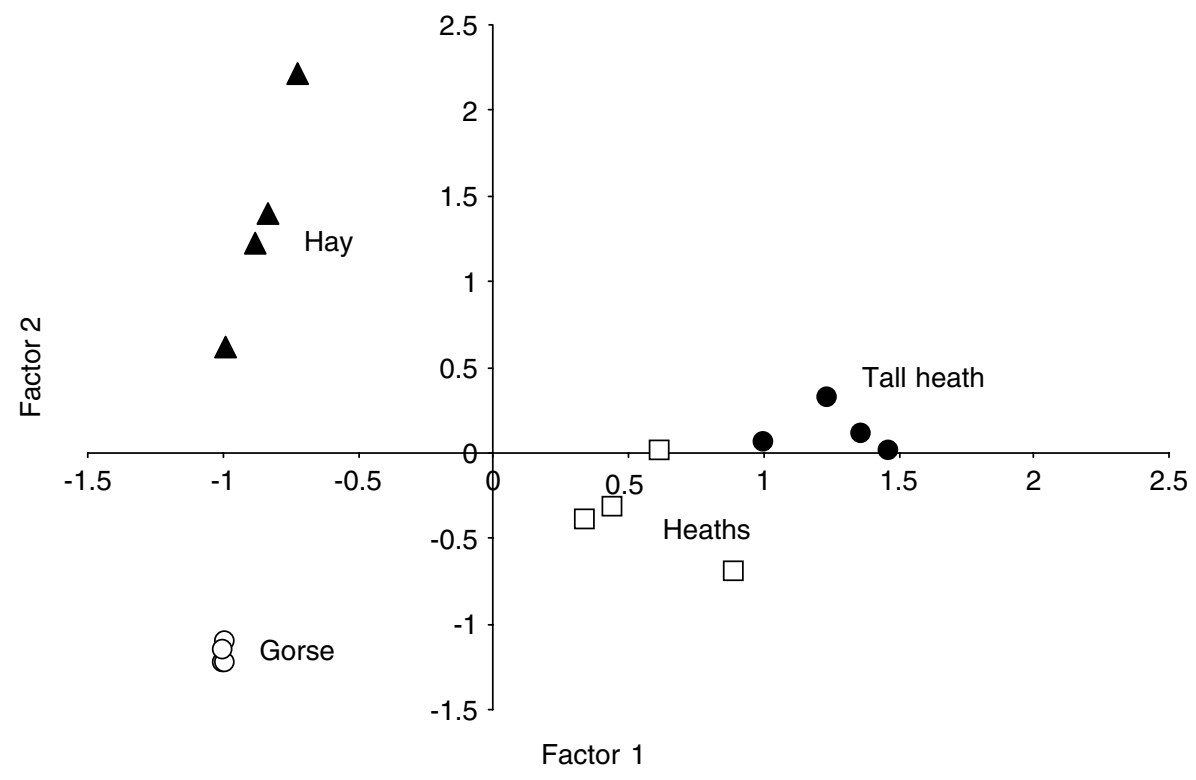

Figure 3. Two-dimensional plot from principal component analysis based on the alkane content of feeds given to groups of non-lactating goats in the third experimental period.

Table 4. Mean $n$-alkane concentration ( $\left.\mathrm{mg} \mathrm{kg}^{-1} \mathrm{DM}\right)$ in faeces of non-lactating goats fed experimentally in three different periods

\begin{tabular}{rrrrrrrrrrr}
\hline Period & Group & $\mathrm{C}_{25}$ & $\mathrm{C}_{26}$ & \multicolumn{1}{c}{$\mathrm{C}_{27}$} & $\mathrm{C}_{28}$ & $\mathrm{C}_{29}$ & $\mathrm{C}_{30}$ & $\mathrm{C}_{31}$ & $\mathrm{C}_{32}$ & $\mathrm{C}_{33}$ \\
\hline 1 & $\mathrm{G} 1$ & 22.6 & 7.5 & 79.6 & 28.3 & 411.3 & 50.8 & 810.9 & 30.2 & 282.1 \\
& $\mathrm{G} 2$ & 40.0 & 14.0 & 118.1 & 38.8 & 583.8 & 76.9 & 1376.6 & 88.0 & 720.2 \\
2 & G3 & 30.1 & 5.9 & 68.0 & 17.8 & 332.2 & 48.0 & 1015.2 & 60.0 & 467.1 \\
& G4 & 29.9 & 6.6 & 77.3 & 20.7 & 415.8 & 51.9 & 1047.9 & 59.4 & 474.9 \\
3 & G5 & 29.8 & 8.3 & 66.8 & 21.5 & 280.5 & 43.0 & 852.4 & 56.0 & 458.3 \\
& G6 & 38.4 & 12.0 & 108.4 & 36.2 & 514.0 & 95.4 & 1746.5 & 129.5 & 788.0 \\
& G7 & 33.5 & 8.6 & 86.6 & 28.1 & 438.1 & 80.6 & 1425.5 & 94.6 & 439.2 \\
\hline
\end{tabular}

samples stood apart on the PCA output, which could mean that this sample showed different plant part composition. The same results were observed in the heath group, with a sample showing different alkane pattern, probably due to a different proportion of plant species and/or plant parts.

In the second experimental period, $L$ perenne leaf/stem, $T$ repens and $U$ gallii seemed to have some similarities in their $n$-alkane profiles, but $L$ perenne spikes and heaths showed different compositions. It is also evident that $L$ perenne spikes have a different $n$ alkane profile from the $L$ perenne leaf/stem, due to the higher concentration of short $n$-alkanes presented by the spike (Table 3). Similar differences were observed by Dove et al. ${ }^{26}$ When comparing the pattern of alkane concentrations of the reproductive tissues with vegetative tissues (leaf, sheath, base and stem) of perennial ryegrass (Lolium perenne cv Victorian), these authors reported a higher concentration in the inflorescence, especially for the shorter $n$-alkanes.

The results of the third experimental period show that $n$-alkane profile of $U$ gallii (gorse) was completely different from the other diet components. In addition, the similarity between heaths and $E$ arborea should be noted. It must be pointed out the high dispersion of the hay samples in the plot, resulting from the high heterogeneity of the hay in terms of its botanical composition.

The mean $n$-alkane concentrations in faeces are presented in Table 4 . As a result of the different $n$-alkane pattern of the diet components, the faecal concentrations of alkanes differed between groups. The groups fed on heaths and/or $E$ arborea (G2, G3, G4, G6 and G7) presented higher concentration of long-chain alkanes, mainly $\mathrm{C}_{29}$ and $\mathrm{C}_{31}$.

The $n$-alkane faecal recoveries of each experimental group are shown in Table 5. The alkane recoveries showed a tendency to increase with carbon-chain length in all groups, being more pronounced in the odd-chain alkanes. Similar trends were obtained in previous reports ${ }^{8-10,23,24}$ although our mean values were higher than the average results reported in these studies, especially for the shorter alkanes. The $n$-alkane faecal recoveries were highly variable among dietary groups. In this study, the stage of maturity of the feeds, the effects of the experimental period and of the diet composition on the alkane faecal recovery could be confounded if the maturity stage of some feeds, in terms of proportion of dead/alive material or leaf/stem plant parts, had been affected by the experimental period. To avoid this, different feeds at similar stages of maturity should have been offered during the same 
Table 5. Mean $n$-alkane recovery in faeces of non-lactating goats fed experimentally in three different periods

\begin{tabular}{|c|c|c|c|c|c|c|c|c|c|c|c|c|}
\hline Period & Group & $\mathrm{C}_{25}$ & $\mathrm{C}_{26}$ & $\mathrm{C}_{27}$ & $\mathrm{C}_{28}$ & $\mathrm{C}_{29}$ & $\mathrm{C}_{30}$ & $\mathrm{C}_{31}$ & $\mathrm{C}_{32}$ & $\mathrm{C}_{33}$ & DMD & SEM \\
\hline \multirow[t]{3}{*}{1} & G1 & 0.32 & 0.37 & 0.45 & 0.51 & 0.58 & 0.60 & 0.66 & 0.63 & 0.74 & 778 & 4.9 \\
\hline & G2 & 0.50 & 0.60 & 0.62 & 0.72 & 0.69 & 0.74 & 0.71 & 0.77 & 0.77 & 730 & 7.8 \\
\hline & $\mathrm{F}$ & $* *$ & $* * *$ & $* * *$ & $* * *$ & $* *$ & $* * *$ & $*$ & $* * *$ & NS & $* *$ & \\
\hline \multirow[t]{3}{*}{2} & G3 & 0.70 & 0.68 & 0.73 & 0.77 & 0.84 & 0.91 & 0.96 & 0.98 & 0.96 & 601 & 4.0 \\
\hline & G4 & 0.95 & 0.73 & 0.87 & 0.79 & 0.90 & 0.95 & 0.97 & 0.95 & 0.92 & 602 & 10.1 \\
\hline & $\mathrm{F}$ & ** & NS & $* *$ & NS & NS & NS & NS & NS & NS & NS & \\
\hline \multirow[t]{4}{*}{3} & G5 & 0.67 & 0.86 & 0.76 & 0.67 & 0.92 & 0.99 & 0.98 & 1.06 & 1.00 & 505 & 14.3 \\
\hline & G6 & 0.73 & 1.08 & 0.87 & 0.95 & 0.96 & 1.00 & 0.96 & 0.96 & 0.94 & 519 & 0.2 \\
\hline & G7 & 0.68 & 0.99 & 0.81 & 0.84 & 0.86 & 0.90 & 0.91 & 0.91 & 0.92 & 563 & 20.3 \\
\hline & $\mathrm{F}$ & NS & $*$ & NS & $* *$ & NS & NS & NS & * & NS & NS & \\
\hline
\end{tabular}

DMD: dry matter digestibility.

SEM: standard error of mean.

NS non significant.

${ }^{*} p<0.05 ;{ }^{* *} p<0.01 ;{ }^{* * *} p<0.001$.

periods, in order to assure that the observed variation in the faecal recoveries would be only due to different diet compositions and not to other factors. However, the aim of this study was to offer different diets reflecting the varying availability of plant species and different phenological stages along the grazing season. Due to the statistical limitations of this experimental design, the effect of diet composition had to be studied within each experimental period. In period 1 (May) the composition of the diet ( $L$ perenne $+U$ gallii or $L$ perenne + heaths) affected significantly the faecal recovery of all alkanes, except $\mathrm{C}_{33}$, with the highest recovery value in both diets. In this period there was also a significant effect $(p<0.01)$ of the diet composition on the in vivo digestibility. However, in period 2 (July), in which there were no differences in the in vivo digestibility between diet treatments, the effect of the diet was only significant for the faecal recoveries of $\mathrm{C}_{25}(p<0.01)$ and $\mathrm{C}_{27}(p<$ 0.01 ). In period 3 (October), the diet composition (hay + heaths $+U$ gallii, hay + heaths $+E$ arborea or hay $+E$ arborea $+U$ gallii) affected significantly the faecal recovery of some even-chain alkanes such as $\mathrm{C}_{26}(p<0.05), \mathrm{C}_{28}(p<0.01)$ and $\mathrm{C}_{32}(p<0.05)$ but it did not affect the digestibility of the diets. From these data, it seems that the alkane faecal recoveries appear to be negatively related with the digestibility of the diet, as they increased from May to October while the digestibility of the diet decreased. Moreover, the effect of the diet composition was significant for almost all alkanes in May, when the digestibility of the whole diet was significantly different between dietary treatments.

The effect of diet composition on the alkane faecal recoveries is still unclear. It has been frequently reported in the literature that the faecal recovery of $n$ alkanes may be affected by diet and also by individual variability. ${ }^{23,28}$ Hendricksen et al, ${ }^{28}$ in steers fed with various tropical grass and lucerne hays, observed that alkane faecal recoveries were highly variable between diets and experiments although, in their study, only the faecal recoveries of $\mathrm{C}_{30}$ to $\mathrm{C}_{36}$ were evaluated. However, Valiente et $a l^{10}$ did not found any consistent diet effect on the alkane faecal recoveries of Rasa Aragonesa ewes fed on different proportions of barley grain and straw. The same results were obtained in cattle by Hendricksen et $a l^{29}$ although, in this study, the effect of diet composition on $n$-alkane faecal recoveries was analyzed by comparing buffelgrass hays at different phenological states. Brosh et $a l^{8}$ also did not find any diet effect on the alkane faecal recoveries when comparing goats, cows and calves fed on different diet compositions. The observations made by these authors seem to be based on the assumptions that animal species (cattle versus goats) and animal age (cows versus calves) do not have any effect on the alkane faecal recoveries. In our opinion the published data do not allow any validation of such assumptions. As stated by Brosh et al, ${ }^{8}$ more studies are needed on the evaluation of possible effects, related to the diet (level of intake, diet composition) and to the animal (species, breed, physiological state), on the alkane faecal recoveries.

Valiente $e t a l^{10}$ pointed out that individual variability may influence the alkane faecal recoveries, as they found that differences between animals can account for up to $85 \%$. Our results showed that the individual variability was related with the alkane chain length, as it was higher in short-chain alkanes (20 to $14 \%$ for $\mathrm{C}_{25}$ to $\left.\mathrm{C}_{28}\right)$ than in long-chain alkanes $\left(10 \%\right.$ from $\mathrm{C}_{29}$ to $\mathrm{C}_{33}$ ), possibly as a result of the higher variability between individuals in the level of absorbance of shortchain alkanes along the digestive tract.

In our study, alkane faecal recoveries seem to be related to the digestibility of the diet. Figure 4 illustrates the relationship between diet digestibility and the faecal recovery of each alkane. Results show that alkane faecal recovery rates decreased significantly with the increase of diet digestibility, this effect being more pronounced for long-chain alkanes in diets with higher digestibility (G1 and G2 diets). For the shorter $n$-alkanes $\left(\mathrm{C}_{25}\right.$ to $\left.\mathrm{C}_{28}\right)$ this relationship was more variable, in particular for the diets with lower digestibility values. These results seem to indicate an increase in the disappearance of alkanes along the digestive tract in diets with higher digestibilities. The 

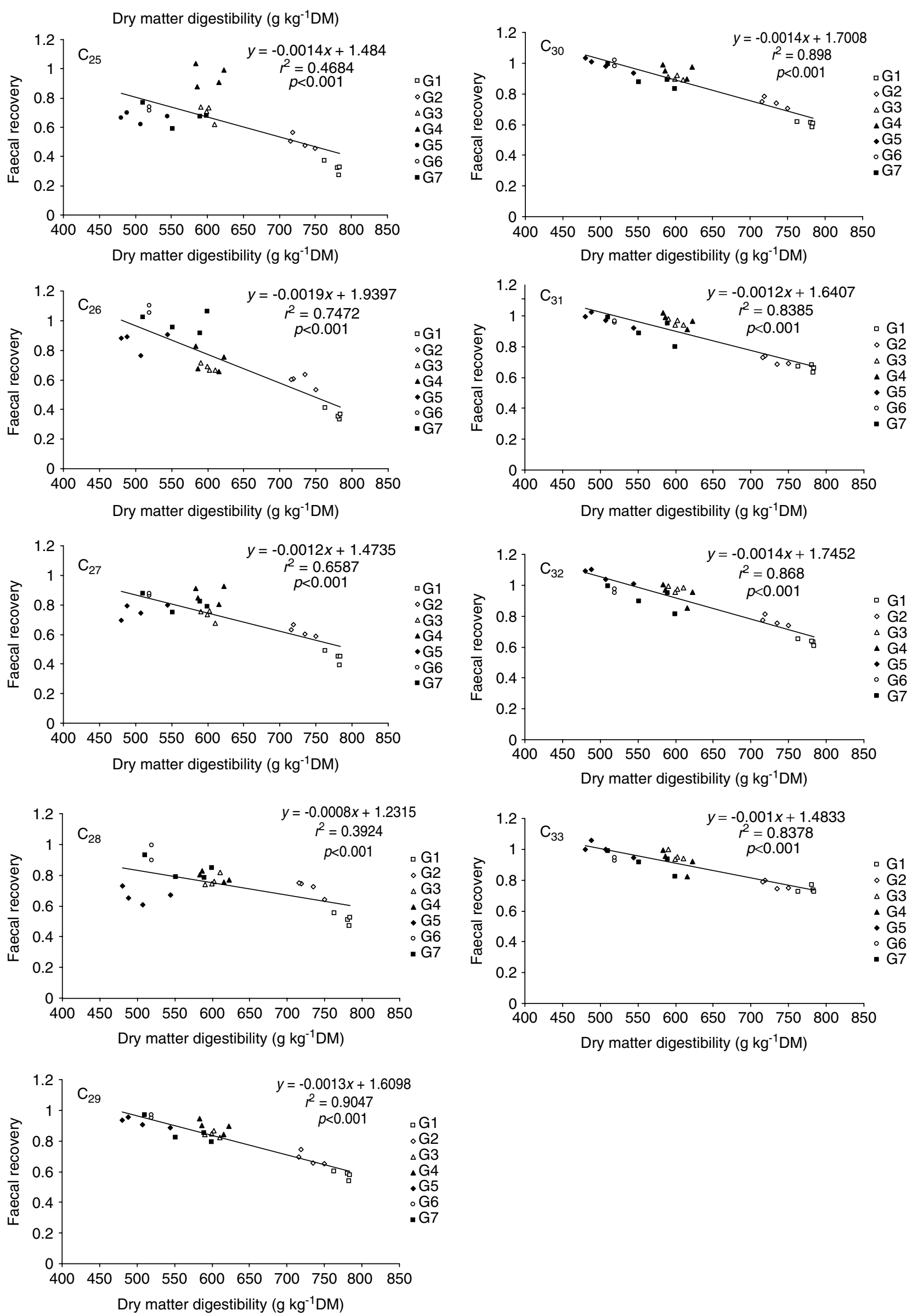

Figure 4. Relationship between diet digestibility and faecal recovery of each $n$-alkane observed with the seven experimental diets. 
higher complexity of the cell wall structure of the diet components used in the second and in the third experimental period, resulting from the advancing maturity stage, may have influenced the alkane availability to absorption in the digestive tract. In fact, the structure of the cuticle, as well as its degree of association with other epidermal components, is highly variable during plant maturation. Therefore, if it is accepted that phenolic compounds are responsible for the linkages of cuticle and the cell wall components, ${ }^{30}$ then it is possible that cuticular waxes will be more accessible at early stages of plant development.

The site and the mechanisms of loss of the $n$-alkanes, in the gastro-intestinal tract need to be elucidated, since only two studies are reported on this subject and their results were not conclusive. Mayes et al, ${ }^{31}$ when dosing $\mathrm{C}_{28}, \mathrm{C}_{32}$ and $\mathrm{C}_{36}$ to sheep, observed that the main site of disappearance of these alkanes was the small intestine. On the contrary, Ohajuruka and Palmquist ${ }^{32}$ found that the alkane losses were essentially in the rumen when using cows.

As far as the effect of the calculation method for estimating diet composition is concerned, the comparison of measured proportions of dietary components and those estimated using $n$-alkanes $\left(\mathrm{C}_{25}\right.$ to $\left.\mathrm{C}_{33}\right)$ is presented in Table 6. The estimations were calculated with correction of faecal recoveries $(\alpha)$, using the mean recoveries for each treatment, or without faecal recovery correction $(\beta)$. The results show that when recovery correction was applied to alkane faecal concentrations, there were no significant differences between measured proportions of diet components and those estimated using the $n$-alkanes. In contrast, when faecal concentrations were not adjusted, only the proportions of $U$ gallii (G2, G6 and G7), T repens (G3), L perenne spike (G4), meadow hay (G7), $E$ arborea (G6 and G7) and heaths (G4 and G7) were not significantly different from the measured proportions. Most of these plant species ( $U$ gallii in G2, G6 and G7; T repens in G3; L perenne spike in G4 and heaths in G7) were not part of the diet. This could be the reason of the accurate estimate, which remained near zero with or without faecal recovery correction. However, the accurate estimate of the proportion of $E$ arborea in the diet, when faecal concentrations were not adjusted for incomplete recovery, could be related with the high concentration in this plant species of long-chain alkanes; those presenting the highest faecal recoveries.

The application of alkanes as markers to estimate diet composition is a simple technique and relies on the

Table 6. Comparisons of measured proportions of dietary components (means) and those estimated (with and without faecal correction) for each group in the first period

\begin{tabular}{|c|c|c|c|c|c|c|}
\hline Groups & Diet components & Measured & Estimated $^{a}$ & Estimated ${ }^{b}$ & SEM & $F$ \\
\hline \multirow[t]{3}{*}{ G1 } & L perenne & $0.710 a$ & $0.701 a$ & $0.557 b$ & 0.0080 & $* * *$ \\
\hline & Heaths & $\mathrm{Ob}$ & $0.006 b$ & $0.086 a$ & 0.0067 & $* * *$ \\
\hline & U gallii & $0.290 b$ & $0.292 b$ & $0.357 a$ & 0.0024 & $* * *$ \\
\hline \multirow[t]{3}{*}{ G2 } & L perenne & $0.715 a$ & $0.710 a$ & $0.625 b$ & 0.0139 & $* *$ \\
\hline & Heaths & $0.285 b$ & $0.287 \mathrm{~b}$ & $0.375 a$ & 0.0131 & $* *$ \\
\hline & U gallii & Oa & Oa & $0.003 a$ & 0.0016 & NS \\
\hline \multirow[t]{5}{*}{ G3 } & L perenne leaf/stem & $0.279 a$ & $0.249 a$ & $0.120 b$ & 0.0214 & $* *$ \\
\hline & L perenne spike & $0.120 \mathrm{a}$ & $0.117 a$ & $0.037 b$ & 0.0059 & $* * *$ \\
\hline & Trepens & Oa & $0.018 a$ & $\mathrm{Oa}$ & 0.0063 & NS \\
\hline & Heaths & $0.300 a$ & $0.300 a$ & $0.277 \mathrm{~b}$ & 0.0049 & $*$ \\
\hline & U gallii & $0.300 b$ & $0.317 \mathrm{~b}$ & $0.567 a$ & 0.0181 & $* * *$ \\
\hline \multirow[t]{5}{*}{ G4 } & L perenne leaf/stem & $0.394 b$ & $0.363 b$ & $0.541 a$ & 0.0318 & $* *$ \\
\hline & L perenne spike & Oa & $0.004 a$ & $0.012 a$ & 0.0038 & NS \\
\hline & Trepens & $0.301 a$ & $0.308 a$ & $0.064 b$ & 0.0203 & $* * *$ \\
\hline & Heaths & $0.305 a$ & $0.305 a$ & $0.265 a$ & 0.0107 & $*$ \\
\hline & U gallii & $\mathrm{Ob}$ & $0.021 b$ & $0.118 a$ & 0.0151 & $* * *$ \\
\hline \multirow[t]{4}{*}{ G5 } & Meadow hay & $0.401 b$ & $0.434 b$ & $0.497 a$ & 0.0142 & $* *$ \\
\hline & Heaths & $0.300 b$ & $0.311 b$ & $0.398 a$ & 0.0054 & $* * *$ \\
\hline & E arborea & $\mathrm{Ob}$ & $0.008 \mathrm{~b}$ & $0.106 a$ & 0.0059 & $* * *$ \\
\hline & U gallii & $0.299 a$ & $0.247 a$ & $\mathrm{Ob}$ & 0.0159 & $* * *$ \\
\hline \multirow[t]{4}{*}{ G6 } & Meadow hay & $0.400 a$ & $0.387 a b$ & $0.371 b$ & 0.0048 & NS \\
\hline & Heaths & $0.300 a$ & $0.295 a$ & $0.274 b$ & 0.0021 & $* *$ \\
\hline & E arborea & $0.300 a$ & $0.291 a$ & $0.341 a$ & 0.0144 & NS \\
\hline & U gallii & Oa & $0.026 a$ & $0.014 a$ & 0.0172 & NS \\
\hline \multirow[t]{4}{*}{ G7 } & Meadow hay & $0.403 a$ & $0.365 a$ & $0.248 a$ & 0.0399 & NS \\
\hline & Heaths & Oa & $0.010 a$ & $0.005 a$ & 0.0065 & NS \\
\hline & E arborea & $0.302 a$ & $0.272 a$ & $0.291 a$ & 0.0197 & NS \\
\hline & U gallii & $0.295 a$ & $0.353 a$ & $0.456 a$ & 0.0476 & NS \\
\hline
\end{tabular}

${ }^{a}$ Corrected with treatment mean faecal recoveries.

b Without recovery correction.

SEM: standard error of mean.

NS: non significant $p>0.05$.

${ }^{*} p<0.05 ;{ }^{* *} p<0.01 ;{ }^{* *} p<0.001$. Values in the same line for each group with different letters are significantly different $(p<0.05)$. 
comparison of the alkane concentrations in faeces and in diet components. To obtain accurate results two conditions are inherent to this procedure: (1) total alkane concentration in diet components must be similar but their alkane profiles have to be different and (2) the $n$-alkane faecal concentrations must be corrected for their incomplete faecal recovery. ${ }^{6}$

With respect to total alkane concentrations, the results presented in Table 3 indicate that there is a large variation between vegetation components and between parts of the same plant species. PCA showed that, in the first experimental period, all components presented different alkane profiles (Fig 1). Nevertheless, the results for the diet of the other two experimental periods show that $T$ repens, $L$ perenne leaf/stem and $U$ gallii (used in the second experimental period) and heaths and $E$ arborea (used in the third experimental period) presented rather resembling alkane profiles. Although the first assumption was not satisfied in these experiments, the component proportions were estimated with high precision.

Dove and Mayes $^{6}$ state that the effects of recovery corrections of alkane concentrations on diet composition estimates depend on the alkane profiles of the feeds. These authors suggest that estimates of diet composition should be obtained with and without faecal recovery corrections in order to evaluate the effect of such adjustments. Our results show that the use of faecal corrections improved the estimates of diet composition in all groups (Table 6). This tendency was not so clear in G6 and G7, as the proportions estimated without faecal correction did not differ significantly from the measured proportion for the majority of the components. The improvement of diet composition estimates when using corrected alkane faecal concentrations was also observed by Brosh et al ${ }^{8}$ using either the individual animal recovery factors or the experiment means in goats and cows.

Although the botanical composition of the group 'heaths' was diverse and different for each experimental period, its proportion in diets was always accurately estimated, even if alkane faecal concentrations were not corrected for incomplete recoveries. This means that, when applying the alkane technique on this type of vegetation, the group 'heaths' will be discriminated even if the proportion of these plant species in the vegetation canopy and/or the feeding selectivity of goats varied along the grazing period. This is an important aspect, because feeding selectivity may change the proportion of a particular species, hence its $n$-alkane contribution to the ingested diet. ${ }^{33}$ This could potentially affect estimates of the diet composition. However, our results with the 'heaths' group and those obtained by Bugalho et $a l^{33}$ when grouping nine grass species into a single 'herbage' component of mixed diets of herbage and browse selected by red deer, seem to indicate that grouping plant species into broad dietary categories composed of species of similar $n$-alkane pattern may be useful when the $n$ alkane technique is to be used in grazing conditions on pastures of high botanical diversity.

Our results indicate that $n$-alkanes can be used as markers to estimate diet composition of goats grazing in heather-gorse communities in the presence of grasses and clover. However, under these conditions, we observed that diet composition and its digestibility affect the faecal recovery of alkanes. For this reason we suggest that the application of these markers in the estimation of the diet selection of goats under grazing conditions should be preceded by a calculation of the actual alkane faecal recoveries for each condition. More research is needed to evaluate the possible effect of diet factors (diet composition, digestibility, level of intake) and animal factors (species, body size, physiological state) on the $n$-alkane recovery and thus on the accuracy of the diet composition estimates.

\section{ACKNOWLEDGEMENTS}

The authors would like to thank to the Carbayal Research Station staff for their help in the field work and to M Mocha and MJ Martínez for collaboration in analytical procedures. The financial support of project AGL2003-05342/GAN by CICYT (Comisión Interministerial de Ciencia y Tecnología) is also gratefully acknowledged.

\section{REFERENCES}

1 Osoro K, Vassallo JM, Celaya R and Martinez A, Livestock Production systems and the vegetation dynamics in less favoured areas (LFAs): developing viable systems to manage seminatural vegetation in temperate LFAs in Spain, Proc 2nd Conf LSIRD network, Macaulay Land use Research Institute, Aberdeen, Scotland, pp 133-143 (1999).

2 Osoro K, Oliván M, Celaya R and Martínez A, Effects of genotype on the performance and intake characteristics of sheep grazing contrasting hill vegetation communities. Anim Sci 69:419-429 (1999).

3 Rook AJ, Dumont B, Isselstein J, Osoro K, WallisDeVries MF, Parente G and Mills J, Matching type of livestock to desired biodiversity outcomes in pastures-a review, Biol Cons 119:137-150 (2004).

4 Van Soest PJ, Nutritional Ecology of the Ruminant, 2nd edn. Comstock, Cornell University Press, Ithaca, NY (1994).

5 Radcliffe JE, Grazing management of goats and sheep for gorse control, NZ F Exp Agric 13:181-190 (1985).

6 Dove $\mathrm{H}$ and Mayes RW, Satellite Meeting: wild and domestic herbivore diet characterization, VI Int Symp Nutr Herbivores, Mérida, Yucatán, México (2003).

7 Kelman W, Bugalho $M$ and Dove H, Cuticular wax alkanes and alcohols used as markers to estimate diet composition of sheep (Ovis aries). Biochem Syst Ecol 31:919-927 (2003).

8 Brosh A, Henkin Z, Rothman SJ, Aharoni Y, Orlov A and Arieli A, Effects of faecal n-alkane recovery in estimates of diet composition. F Agric Sci 140:93-100 (2003).

9 Dove H, Freer $M$ and Foot JZ, The nutrition of grazing ewes during pregnancy and lactation: a comparison of alkane-based and chromium/in vitro-based estimates of herbage intake. Aust f Agric Res 51:765-777 (2000).

10 Valiente OL, Delgado P, de Vega A and Guada JA, Validation of the n-alkane technique to estimate intake, digestibility, and diet composition in sheep consuming mixed grain:roughage diets. Aust F Agric Res 54:693-702 (2003). 
11 Chen W, Scott J, Blair R, Lefroy R, Hutchinson K, King K and Harris C, Diet selection and productivity of sheep grazing contrasting pastures. Aust f Agric Res 53:529-539 (2002).

12 Lewis RM, Magadlela AM, Jessop NS and Emmans GC, The ability of the n-alkane technique to estimate intake and diet choice of sheep, Anim Sci 77:319-327 (2003).

13 Dove H, Wood JT, Simpson RJ, Leury BJ, Ciavarella TA, Gatford KL and Siever-Kelly C, Spray-topping annual grass pasture with glyphosate to delay loss of feeding value during summer. III. Quantitative basis of the alkane-based procedures for estimating diet selection and herbage intake by grazing sheep, Aust $\mathcal{F}$ Agric Res 50:475-485 (1999).

14 Osoro K, Oliván M, Martínez A, García U and Celaya R, Diet selection and live weight changes in domestic ruminants grazing on heathland vegetation with areas of improved pastures, Proc VI Int Symp Nutr Herbivores, Tropical and Subtropical Agroecosystems, Vol 3, pp. 1-3, 491-494 (2003).

15 Mayes RW, Lamb CS and Colgrove PM, The use of dosed and herbage $\mathrm{n}$-alkanes as markers for the determination of herbage intake, f Agric Sci 107:161-170 (1986).

16 Oliván $\mathrm{M}$ and Osoro $\mathrm{K}$, Effect of temperature on alkane extraction from faeces and herbage, 7 Agric Sci 132:305-312 (1999).

17 Oliván M, Dove H, Mayes RW and Hoebee SE, Recent developments in the use of alkanes and other plant wax components to estimate intake and diet composition in herbivores. Rev Port Zootec VI: 1-26 (1999).

18 Salt CA, Mayes RW, Colgrove PM and Lamb CS, The effects of season and diet composition on the radiocaesium intake by sheep grazing on heather moorland. F Appl Ecol 31:125-136 (1994).

19 AOAC, Official Methods of Analysis, 14th edn. Association of Official Analytical Chemists, Washington, DC (1990).

20 Van Soest PJ, Robertson JB and Lewis BA, Methods for dietary fiber, neutral detergent fiber, and nonstarch polysaccharides in relation to animal nutrition, $\mathcal{F}$ Dairy Sci 74:3583-3597 (1991).

21 JMP, User's Guide: Statistical Discovery Software, Version 5, SAS Inst Inc, Cary, NC (2003).

22 Hogdson J and Eadie J, Vegetation resources and animal nutrition in hill areas: agricultural and environmental implications, in Hill Land Symp, ed by O'Toole M. An Foras Taluntais, Dublin, pp 118-133 (1984).
23 Dove $\mathrm{H}$ and Mayes RW, The use of plant wax alkanes as markers substances in studies of the nutrition of herbivores: a review. Aust F Agric Res 42:913-957 (1991).

24 Dove $\mathrm{H}$ and Mayes RW, Plant wax components: a new approach to estimating intake and diet composition in herbivores. $F \mathrm{Nutr}$ 126:13-26 (1996).

25 Oliván $\mathrm{M}$ and Osoro K, Utilización de la técnica de los n-alcanos en estudios de ingestión y selección de dieta de los rumiantes en pastoreo: revisión. Inform Téc Econ Agraria 93A:193-208 (1997).

26 Dove H, Mayes RW and Freer M, Effects of species, plant part, and plant age on the n-alkane concentrations in the cuticular wax of pasture plants. Aust f Agric Res 47:1333-1347 (1996).

27 Smith DG, Mayes RW and Raats JG, Effects of species, plant part, and season of harvest on n-alkane concentrations in the cuticular wax of common rangeland grasses from southern Africa. Aust f Agric Res 52:875-882 (2001).

28 Hendricksen RE，Reich MM，Roberton RF，Reid DJ，Gazzola C, Rideout JA and Hill RA, Estimating the voluntary intake and digestibility of buffel-grass and lucerne hays offered to Brahman-cross cattle using n-alkanes. Anim Sci 74:567-577 (2002).

29 Hendricksen RE, Gazzola C, Reich MM, Roberton RF, Reid DJ and Hill RA, Using molasses as an alternative to controlled release devices for administering n-alkane markers to cattle. Anim Sci 76:471-480 (2003).

30 Himmelsbach DS, Structure of forage cell walls-session synopsis, in Forage cell wall structure and digestibility, ed by Jung HG, Buxton DR, Hatfield RD and Ralph J. SSSA Publishing, Madison, pp 271-283 (1993).

31 Mayes RW, Lamb CS and Colgrove PM, Digestion and metabolism of dosed even-chain and herbage odd-chain nalkanes in sheep, Proc 12th Gen Meet Eur Grassld Fed, Dublin, pp 159-163 (1988).

32 Ohajuruka OA and Palmquist DL, Evaluation of n-alkanes as digesta markers in dairy cows. F Anim Sci 69:1726-1732 (1991).

33 Bugalho M, Mayes RW and Milne JA, The effects of feeding selectivity on the estimation of diet composition using the n-alkane technique, Grass Forage Sci 57:224-231 (2002). 